\title{
The R\&D Tax Credit And Its Implications For Small Business
}

Spence L. Wise (E-mail: swisegasou.edu), Georgia Southern University Morgan P. Miles (E-mail: mmiles@gasou.edu), Georgia Southern University

\begin{abstract}
The present study describes how the $R \& D$ tax credit functions, explores the impact of the $R \& D$ tax credit on SMEs, and proposes that the $R \& D$ tax credit is granted permanent status in the US tax code. This would provide a permanent tax incentive for SMEs to create new technology based intellectual property. Similar tax credits have been effectively adopted in Europe to stimulate high technology business creation.
\end{abstract}

\subsection{Introduction}

$E$ ntrepreneurship and innovation are increasingly perceived by corporate executives as important tools for business development and as paths to superior financial returns for both large corporations and small and medium sized enterprises (SMEs) (Block and MacMillan 1993; Carrier 1994, 1996). Boucher and Abdala (1999: 78) report that "over two-thirds of the average annual increase in per capita wealth of the United States is attributable to technological change as it becomes embodied in new products, new capital equipment, and new production methods." Governments have also become keenly aware of the ability of corporate entrepreneurship to enhance economic competitiveness and thereby, promote social welfare. For example, policy makers from both the U.S. and the European Community have recently espoused the many manifestations of corporate entrepreneurship as tools of productivity enhancement, economic development, and job creation (see for example Birch 1989; Byrne 1993; Withers 1995; Chancellor of the Exchequer 1998; Secretary of State for Trade and Industry 1998; Confederation of British Industry 1999; van Osnabrugge and Robinson 1999).

Policy makers in the U.S. and Europe understand that entrepreneurship by large and small corporations can be influenced both by regulatory controls and reward structures created by government (see for example Burch 1986; Chrisman, Hoy, and Robinson 1987; Chrisman and Katrishen 1994; Hulpke and Byrnes 1994; Morris 1998). Governments often use tax incentives to reward and encourage activities that promote social welfare objectives, such as employment and income creation. Government policy makers, globally, tend to rely on two major categories of tools to induce entrepreneurial activities by corporations: (1) tax incentives; and (2) direct government support.

The European Community policy on economic competitiveness suggests that corporate entrepreneurship is essential for future prosperity (Secretary of State for Trade and Industry 1998). Many European Community nations have crafted programs to support and encourage entrepreneurship (see for example Hulpke and Byrnes 1994; ; Bronwyn and Van Reenen 2000; Moncada-Paterno-Castello, Tubke, Howells, and Carbone 2000); and compared to the U.S., many member nations of the European Community have taken a more formal and proactive approach to induce corporate entrepreneurship. For example, government support for entrepreneurship is seen as such a critical issue in the United Kingdom that the British Government has created a policy office specifically for the support of corporate entrepreneurship, and established direct economic rewards for corporate entrepreneurship through a recent proposal to create tax incentives for corporate venturing (Inland Revenue 1999).

Readers with comments or questions are encouraged to contact the authors via email. 
While U.S. government policy makers have not explicitly promoted corporate entrepreneurship, government policy has provided support for innovation through the establishment of tax credits for investment and R\&D. In the U.S. the major federal tax incentive for encouraging entrepreneurship and innovation in SMEs is the research tax credit. Recent tax legislation ${ }^{1}$ has extended the R\&D credit until June 30, 2004. Table 1 details the lifecycle of the research tax credit in the U.S. A total of eleven different pieces of tax legislation have prolonged the life of this popular credit. It should be noted that tax legislation did not arrive in time and a credit was not allowed for research expenditures from July 1, 1995 to June 30, 1996. Companies in high technology sectors such as computers and pharmaceuticals often are involved in multi-year research projects, and the current temporary status of the tax credit greatly constrains long term investments in R\&D.

\title{
TABLE 1: The Many Temporary Lives Of The Research Credit
}

\author{
1. 1981 ERTA Provision-The Economic Recovery Tax Act of 1981 added a tax credit for certain qualified research \\ expenditures paid or incurred after June 30,1981, but before January 1, 1986. (1981 ERTA, §221(d)) \\ 2. 1986 TRA Credit Extension-The 1986 Tax Reform Act of 1986 extended the credit for expenditures paid or incurred \\ after December 31, 1985, but before January 1, 1989. (1986 TRA, §231(a)) \\ 3. 1988 TAMRA Credit Extension-The Technical and Miscellaneous Revenue Act of 1988 extended the credit for \\ expenditures incurred after December 31, 1988, but before January 1, 1990. (1988 TAMRA, §4007(a)) \\ 4. 1989 RRA Credit Extension-The 1989 Revenue Reconciliation Act extended the credit for expenditures incurred after \\ December 31, 1989, but before January 1, 1991. (1989 RRA, §7110) \\ 5. 1990 RRA Credit Extension-The 1990 Revenue Reconciliation Act extended the credit for expenditures incurred after \\ December 31, 1990, but before January 1, 1992. (1990 RRA, §11402(a)) \\ 6. 1991 Tax Extension Act-The Tax Extension Act of 1991 extended the credit for expenditures incurred after \\ December 31,1991, but before July 1, 1992. (1991 Extension Act, §102(1)) \\ 7. Revenue Reconciliation Act of 1993-The Revenue Reconciliation Act of 1993 extended the credit for expenditures \\ incurred after June 30, 1992, but before July 1, 1995. (1993 RRA, §13111) \\ 8. 1996 Small Business Job Act-The Small Business Job Protection Act of 1996 extended the credit for expenditures \\ incurred after June 30, 1996, but before June 1, 1997. (P.L. 104-188, §1204(a)) \\ 9. The Taxpayer Relief Act of 1997-The Taxpayer Relief Act of 1997 extended the credit for expenditures incurred after \\ June 1, 1997, but before July 1, 1998. (P.L. 105-34, §601) \\ 10. 1998 Extension Act-The 1998 Extension Act extended the credit for expenditures incurred after June 30,1998, but \\ before July 1, 1999. (P.L. 105-277, §1001) \\ 11. 1999 Tax Relief Extension Act-The 1999 Tax Relief Extension Act extended the credit for expenditures incurred after \\ June 30,1999, but before July 1, 2004. (P.L. 106, §502)
}

Unfortunately an understanding of the implications of tax policy for SMEs has not progressed as quickly as enthusiasm for the practice. Consequently, while the wealth creating potential of entrepreneurship is increasingly recognized, current knowledge regarding the implications of the interrelationships between tax policy and entrepreneurship for SMEs remain quite limited. The uncertainty associated with the temporary nature of the research credit makes it difficult for companies to plan. The time has come for Congress to make the research credit a permanent and not a temporary part of our federal income tax system.

\subsection{Purpose}

The purpose of this manuscript is to describe how R\&D tax credit functions and explore its impact on entrepreneurial activities by SMEs. In addition, this paper advocates the establishment of a permanent R\&D tax credit to enhance the technological competitiveness of the US small business sector.

\subsection{How Does the Tax Credit Functions?}

SMEs organized as sole proprietorships, partnerships, or corporations are entitled to claim a research credit. $^{2}$ In the case of SMEs organized as either sole proprietorships or partnerships the credit will pass through to the owner(s) individual tax return(s). The total tax credit is actually the sum of two parts: an incremental research activities credit and a basic research credit. ${ }^{3}$ The credit is twenty percent of the increase in qualified research 
expenses for the tax year, plus twenty percent of the increase in basic research payments made to qualified organizations. Recent tax legislation added in two suspension periods for claiming the credit. The periods are from July 1, 1999 until September 30, 2000 and from October 1, 2000 until September 30, 2001. ${ }^{4}$ The research credit may be claimed on the first day after the suspension period expires by filing an amended income tax return. ${ }^{5}$ The research credit is claimed on IRS Form 6765 as part of the general business credit and is subject to those limitations on allowable amounts. Taxpayers are also required to reduce the research expense and amortization deductions by the corresponding amount of the credit claimed. The law does provide for a reduced alternative incremental research credit which does not require such a reduction. ${ }^{6}$ Finally, the research credit is a non-refundable credit in that the credit taken in any year cannot exceed the tax liability for that year.

\subsection{Amount of the Credit}

The incremental research activities credit is based on an increase in research expenditures. The credit is twenty percent of the excess of qualified research expenses for the tax year over a base amount, which is an average figure for a specified period preceding the tax year. ${ }^{7}$ While the actual calculation of the incremental research activities credit is very complicated and requires the services of a competent tax professional who has experience in dealing with the research credit; the following example will offer a general view of how the incremental research activities credit is calculated.

\section{Example \# 1}

Acme corporation has $\$ 2,000,000$ of research expenditures for the current tax year. During its base period, Acme spent $\$ 400,000$ on research and had gross receipts of $\$ 4,000,000$. The average annual gross receipts for the four preceding tax years is $\$ 10,000,000$.

First, the fixed based percentage is calculated:

$$
\$ 400,000 / \$ 4,000,000=10 \%
$$

Then the research credit is calculated as follows:

Qualified research expenditures for the current year:

Base amount for the year:

Average annual gross receipt $\$ 10,000,000$

Times the fixed-base percentage ……....... $\quad \frac{\mathrm{x} .10}{21,000,000}$

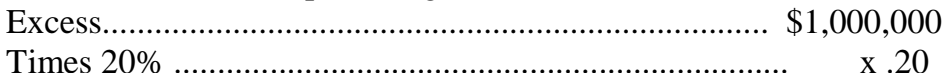

Research Credit ............................................................\$ $\$ \overline{200,000}$

The calculation is made more difficult than normal because two different prior period combinations are required. First, one set of prior years is used to determine the "fixed based percentage" and then another set of prior years is used for calculation of the "average annual gross receipts." However, the example does gives an indication of the benefits, while limited, that are offered by the incremental research credit.

The second element of the research credit computation is twenty percent of the basic research payments in excess of a base amount. ${ }^{8}$ This is often referred to as the "university research credit." The credit is available to SMEs for expenditures for basic research performed by universities, colleges, and other qualified organizations. Basic research is defined as any original investigation for the advancement of scientific knowledge not having a specific commercial objective. This calculation is complex and will, like the previous calculation, require the services of a competent tax professional. However, the following example will offer a general view of how the basic research activities credit is calculated: 


\section{Example \# 2}

Beta Corporation pays $\$ 150,000$ to John Smith University for basic research. Assume that Beta's base amount for the credit calculation is $\$ 100,000$.

$(\$ 150,000-\$ 100,000) \times 20 \%=\$ 10,000$ Basic Research Credit

It is important to note that the $\$ 100,000$ base amount is treated as research expenses for ${ }^{9}$ the regular incremental research activities credit computation.

\subsection{Eligible Expenditures}

Basically wage and supply expenses qualify as research expenditures if the research relates to discovering technological information that is intended for use in the development of a new or improved business component of the taxpayer. If the research is performed by the tax entity (taxpayer or employees) all the research expense qualifies. If the research is conducted outside the tax entity under contract, only sixty-five percent of the research expenses qualify. This increases to seventy-five percent if payment is made to a tax-exempt charity. ${ }^{10}$

\section{Example \#3}

Gamma Corporation incurs the following research expenses during the current tax year:

In-house wages and supplies $\$ 100,000$

Paid to outside companies to conduct research 300,000

Gamma's qualified research expenses are calculated as follows:

$\$ 100,000+(\$ 300,000 \times 65 \%)=\$ 295,000$

Research expenses must first satisfy the requirements of Code Sec. 174, deduction or amortization of research and experimental expenditures. The research must also be undertaken for the purpose of discovering information that is technological in nature. The application of the research must be intended to be useful in the development of a new or improved business component of the taxpayer, and must involve a process of experimentation related to functional aspects, performance, reliability, or quality of a business component. In practice the costs incidental to the development of an experimental or pilot model, a plant process, a product, a formula, an invention, or similar property should qualify for the research credit. It is also important to remember that the tax law does not require that the research be successful in order to qualify for the credit. ${ }^{11}$

The tax code and regulations concerning the research credit does not give specific examples of qualifying research. However, the code and regulations do offer examples of some expenses which do not qualify. Table 2 provides a summary of some of these nonqualifying expenses.

\subsection{Internal-Use Software}

Most of us can envision research involving the development of computer software. If the computer software is a product to be sold, there seems to be no special problem. Unfortunately, a prior court case ${ }^{12}$ has been interpreted as denying taxpayers a research credit for the development of internal-use software. Recently, a new court decision ${ }^{13}$ did recognize that at least some of the research expenses associated with internal-use software could qualify for the credit. This new court decision established a higher technology threshold for the development of internal-use software than for other types of research. Despite this higher threshold, the decision does provide hope that the research credit may apply to other internal-use software projects. 
TABLE 2: Ineligible Activities

1. Research done outside the United States, the Commonwealth of Puerto Rico, or any possessions of the United States (IRC $\$ 41(d)(4))$.

2. $\quad$ Research in the social sciences, arts, or humanities (IRC $\S 41(\mathrm{~d})(4)$ ).

3. Ordinary testing or inspection of materials or products for quality control. (Reg. §1.174-2(a)(1)).

4. $\quad$ Market and Consumer Research (Reg. §1.174-2(a)(1)).

5. $\quad$ Advertising or promotion expenses (Reg. $\$ 1.174-2(a)(1))$.

6. Management studies and efficiency surveys (IRC $\$ 41(\mathrm{~d})(4))$.

7. Research to find and evaluate mineral deposits, including gas and oil (IRC $\$ 174(d)$ ).

8. Acquisition or improvement of land or of certain depreciable or depletable property used in research (IRC $\$ 174(c)$ ).

9. Acquisition of another person's patent, model, production, or process (Reg. §174-2(a)(1)).

10. Research funded by another person, or any governmental entity, by means of a grant or contract (IRC $\S 41(d)(4))$.

11. Research conducted after commercial production (IRC $\$ 41(\mathrm{~d})(4)$ ).

12. Research for the adaptation of existing business components (IRC $\S 41(\mathrm{~d})(4)$ ).

13. Research for the duplication of an existing business component (IRC§41(d)(4)).

\subsection{Internal-Use Software}

Most of us can envision research involving the development of computer software. If the computer software is a product to be sold, there seems to be no special problem. Unfortunately, a prior court case ${ }^{12}$ has been interpreted as denying taxpayers a research credit for the development of internal-use software. Recently, a new court decision ${ }^{13}$ did recognize that at least some of the research expenses associated with internal-use software could qualify for the credit. This new court decision established a higher technology threshold for the development of internal-use software than for other types of research. Despite this higher threshold, the decision does provide hope that the research credit may apply to other internal-use software projects.

The court ruled that research connected to the development of internal-use software must first meet the four general tests required of all qualified research expenditures. These four tests are: (1) Code Sec. 174 eligibility; (2) discovery, (3) business component, (4) and process-of experimentation tests. The court further added the following three additional tests:

(1) The software must be innovative. This test is met when the new software is expected to result in a reduction of cost, or improvement in speed that is substantial and economically significant. The court offered examples of internal-use software that will not meet this test. It identified software used in general and administrative functions such as payroll, bookkeeping, or personnel management or in providing noncomputer services such as accounting, consulting, or banking services as noninnovative software.

(2) The software development must involve significant economic risk. The test is met when the taxpayer commits substantial resources to the development and there is a substantial uncertainty because of technical risk that such resources would be recovered within a reasonable period.

(3) The software is not commercially available for use by the taxpayer. Fortunately, the court concluded that mere modification of commercially available software would pass this last test.

\subsection{Conclusions And Managerial Implications}

This paper has attempted to illustrate that the R\&D tax credit enhances the economic viability of innovative activities. However, the temporary nature of the tax credit constrains long term planning. The financial implications of the R\&D tax credit for SME owners and managers are very positive; the R\&D credit can be used to help subsidize research and development activities designed to innovate the SMEs' products and/or processes. These innovative activities can help create, maintain, and enhance the SMEs' competitive advantage. Additional tax relief is provided when the R\&D activities are contracted out to a tax-exempt charity. However, due to the complex and dynamic nature of the R\&D tax credit it is important to use the ineligible activities described in Table 2 as a guideline and to seek experienced tax advise. 
In summary, the R\&D tax credit is beneficial to both large corporations and SMEs. However, if the tax credit could be granted permanent status in the U.S. tax code it would tend to encourage more innovation by SMEs.

\subsection{Suggestions For Future Research}

The effectiveness of tax policy designed to encourage innovation by SMEs is a topic that has been largely neglected by entrepreneurship scholars. While we propose the establishment of permanent R\&D tax credits as a policy mechanism to stimulate innovation by SMEs, there is little empirical evidence to support its effectiveness. Future research may focus on the impact of the R\&D tax credit in stimulating business creation, entrepreneurship, and innovation by SMEs. For example, it may be helpful for policy makers to understand the long-term relationship (if any) between the establishment of permanent $R \& D$ tax credits and the investment in $R \& D$ by SMEs. In addition, the relationship between the adoption of the R\&D tax credit and the creation of R\&D based business ventures, the growth in primary and secondary employment, patent applications, and expansion of the tax base could be assessed. In sum, a better understanding of the effect of $R \& D$ tax credits on the creation of technology based ventures may facilitate the establishment of a permanent R\&D tax credit in the United States as tool to support SME business creation and expansion.

\section{Endnotes}

1. 1999 Tax Relief Extension Act.

2. Code Sec. 41.

3. Code Sec. 41(a).

4. Code Sec. 41, as amended by Tax Relief Extension Act of 1999, P.L. 106-170.

5. Art. Sec. 502 of the Tax Relief Extension Act of 1999, P.L. 106-170.

6. Code Sec. 41(c)(4), as amended by Tax Relief Extension Act of 1999, P.L. 106-170.

7. Code Sec 41(c)(1).

8. Code Sec. 41(e).

9. Code Sec. 41(b)(2)(A).

10. Code Sec. 41(b)(3)(A).

11. Reaffirmed by the conference report to the Tax and Trade Relief Extension Act of 1998.

12. United Stationers, Inc., CA-7, 99-1 USTC §50,136, aff'g DC Ill, 97-2 USTC§ 50,994.

13. Norwest corporation and subsidiaries, 110 TC 454.

\section{References}

1. Bargeman, R. A., "Corporate Entrepreneurship and Strategic Management: Insights from a Process Study," Management Science, Vol. 28, No. 2, pp. 223-244, 1983.

2. _ "Managing the Internal Corporate Venturing Process," Sloan Management Review, Vol. 25, No. 2, pp. 33-48, 1984.

3. Birch, D. L., "Change, Innovation, and Job Creation," Journal of Labor Research, Vol. 10, No. 1, pp. 3338, 1989.

4. Block, Z. and I. C. MacMillan, Corporate Venturing: Creating New Businesses Within the Firm, Harvard Business School Press, Boston, 1993.

5. Boucher, T. O. and M. T. Abdala, "The Research and Experimentation Tax Credit-An Engineering Economist's Perspective," The Engineering Economist, Vol. 44, No. 1, pp. 78-109, 1999.

6. Bronwyn, H. and J. Van Reenen, "How Effective Are Fiscal Incentives for R\&D? A Review of the Evidence," Research Policy, Vol. 29, Nos. 4 and 5, pp. 449-469, 2000.

7. Burch, J. G., Entrepreneurship, John Wiley \& Sons, New York, 1986.

8. Byrne, J. A., "Enterprise: How Entrepreneurs are Reshaping the Economy-And What Big Companies Can Learn," Business Week, Special Issues, pp. 10-18, October 22, 1993.

9. Carrier, C., "Intrapreneurship in Large Firms and SMEs: A Comparative Study," International Small Business Journal, Vol. 12, No. 3, pp. 54-61, 1994. 
10. Carrier, C., "Intrapreneurship in Small Businesses: An Exploratory Study," Entrepreneurship Theory and Practice, Vol. 21, No. 1, pp. 5-20, 1996.

11. Chancellor of the Exchequer, Steering a Stable Course for Lasting Prosperity: Pre-Budget Report November 1998, London, 1998.

12. Chrisman, J. J., F. Hoy, and R. B. Robinson, Jr., "New Venture Development: The Costs and Benefits of Public Sector Assistance," Journal of Business Venturing, Vol. 2, No. 4, pp. 315-328, 1987.

13. and F. Katrishen, "The Economic Impact of Small Business Development Center Counseling Activities in the United States; 1990-1991," Journal of Business Venturing, Vol. 9, No. 4, pp. 271-280, 1994.

14. Confederation of British Industry, Connecting Companies: Using Corporate Venturing for Growth, Confederation of British Industry, London, 1999.

15. Covin, J. G. and M. P. Miles, "Corporate Entrepreneurship and the Pursuit of Competitive Advantage," Entrepreneurship Theory and Practice, Vol. 23, No. 3, pp. 47-63, 1999.

16. Hulpke, J. F. and T. Byrnes, "SBDC, SBI and SCORE in the Emerald Isle: Management Assistance Programs in Ireland," Journal of Small Business Management, Vol. 32, No. 4, pp. 78-83, 1994.

17. Inland Revenue, Corporate Venturing Relief: A Technical Note by the Inland Revenue, London, 1999.

18. McNally, K., Corporate Venture Capital: Bridging the Equity Gap in the Small Business Sector. Routledge, London, 1997.

19. Moncada-Paterno-Castello, P., A. Tubke, J. Howells, and M. Carbone, The Impact of Corporate Spin-offs on Competitiveness and Employment in the European Union, European Commission Joint Research Centre, Seville, 2000.

20. Morris, M. H., Entrepreneurial Intensity: Sustainable Advantage for Individuals, Organization, and Societies: 93-111, Quorum Books, Westport, CT, 1998.

21. Secretary of State for Trade and Industry, Our Competitive Future: Building the Knowledge Driven Economy. London, 1998.

22. Sharma, P. and J. J. Chrisman, "Toward a Reconciliation of the Definitional Issues in the Field of Corporate Entrepreneurship," Entrepreneurship Theory and Practice, Vol. 23, No. 3, pp. 11-28, 1999.

23. Takahashi, D., "Intel Rolls Dice on Tech Upstarts-And Hits Jackpot," The Wall Street Journal, pp. C1 and C3, Tuesday, February 8, 2000.

24. van Osnabrugge, M. and R. J. Robinson, "A Comparison of Business Angel and Venture Capitalist Investment Procedures: An Agency Theory-Based Analysis," HBS Working Paper WP 99/130, Harvard Business School, 1999.

25. Whitney, D., Corporate New Venture at Procter and Gamble, Case 9-897-088, Harvard Business School, Boston, MA, 1997.

26. Withers Solicitors, Gateway to Growth: A Study of Corporate Venturing, London, 1995.

27. _ _ Window on Technology: Corporate Venturing in Practice, London, 1997. 
Notes 